\title{
NOD2/CARD15: geographic differences in the Spanish population and clinical applications in Crohn's disease
}

\author{
M. Barreiro-de-Acosta ${ }^{1}$, J. L. Mendoza ${ }^{2}$, R. Lana ${ }^{3}$, J. E. Domínguez-Muñoz ${ }^{1}$ and M. Díaz-Rubio ${ }^{2}$ \\ ${ }^{1}$ Department of Gastroenterology. Hospital Universitario Santiago de Compostela. A Coruña, Spain. ${ }^{2}$ Departments of \\ Gastroenterology (Inflammatory Bowel Disease Unit) and ${ }^{3}$ Internal Medicine. Hospital Clínico San Carlos. Madrid, \\ Spain
}

\begin{abstract}
Crohn's disease (CD) is a genetically complex disease in which both genetic susceptibility and environmental factors play key roles in the development of the disorder. NOD2/CARD15 mutations are associated with CD. NOD2 encodes for a protein that is an intracellular receptor for a bacterial product (muramyl dipeptide), though the exact functional consequences of these mutations remain the subject of debate. NOD2/CARD15 mutations are associated with ileal $\mathrm{CD}$, with stricturing behavior, and possibly with a more complicated course of CD. NOD2/CARD15 mutations associated with $\mathrm{CD}$ have demonstrated heterogeneity across ethnicities and populations throughout the world, with regional variations across Europe and Spain.

However, "NOD2/CARD15 testing" is not yet ready for use in the clinical setting. One of the reasons is that we know that these genetic variants increase the risk of disease only marginally, and many healthy individuals carry the risk alleles, At present it is not recommended to screen first-degree relatives, because we do not have the ability to prevent the disease at the present time.
\end{abstract}

Key words: NOD2/CARD15. Crohn's disease. Epidemiology. Inflammatory bowel disease.

\section{RESUMEN}

La enfermedad de Crohn (EC) es una enfermedad compleja desde el punto de vista de la genética puesto que para el desarrollo de la enfermedad se tiene que producir una interacción entre factores genéticos y ambientales. Las mutaciones del gen NOD2/CARD15 se han asociado con la susceptibilidad a padecer la EC. El gen NOD2/CARD15 codifica una proteína que actúa como un receptor intracelular de la proteína dipeptidomuramil que se encuentran en la pared de cubierta de algunas bacterias.

Received: 14-09-09.

Accepted: 17-09-09.

Correspondence: Manuel Barreiro de Acosta. Servicio de Aparato Digestivo. Hospital Clínico Universitario. C/ Choupana, s/n. 15706 Santiago de Compostela. A Coruña, Spain.e-mail: manubarreiro@hotmail.com
Actualmente se desconoce cuál es el papel exacto de estas mutaciones en el funcionamiento de la proteína NOD2/CARD15. Estas mutaciones se han asociado con la localización en intestino delgado de la enfermedad, el comportamiento fibroestenosante y con un curso más grave de la enfermedad. Las tres mutaciones asociadas con la EC presentan una distribución desigual entre las diferentes razas y áreas geográficas del mundo, con variaciones a lo largo de Europa y España. La determinación de las mutaciones del NOD2/CARD15 no se puede utilizar todavía en la práctica clínica. La principal razón es que estas variantes genéticas sólo incrementan el riesgo de una forma marginal y los podemos identificar en muchos sujetos sanos. Actualmente no se recomienda realizar estudios de despistaje en familiares de primer grado que padecen la EC porque no disponemos de ninguna medida preventiva para evitar la enfermedad.

Palabras clave: NOD2/CARD15. Enfermedad de Crohn. Epidemiología. Enfermedad inflamatoria intestinal.

Barreiro-de Acosta M, Mendoza JL, Lana R, Domínguez-Muñoz JE, Díaz-Rubio M. NOD2/CARD15: geographic differences in the Spanish population and clinical applications in Crohn's disease. Rev Esp Enferm Dig 2010; 102: 321-326.

\section{ABBREVIATIONS}

UC: ulcerative colitis.

CD: Crohn's disease.

IBD: inflammatory bowel disease.

NOD2/CARD15: nucleotide oligomerization domain 2/caspase recruitment domain 15 .

\section{INTRODUCTION}

Many questions remain to be answered in the physiopathology of inflammatory bowel disease (IBD). We now know that both genetic and environmental factors are implicated, and that upon interacting among each other, 
these factors lead to an altered immune response-allowing initiation and progression of the intestinal inflammatory process to the point where it becomes chronic. Many epidemiological studies point to the participation of a genetic component in susceptibility to developing IBD in the form of both ulcerative colitis (UC) and Crohn's disease (CD). The ethnic differences in the prevalence of the disease are known, with a clear predominance among Caucasians and particularly among Jews. Concordance in mono- and dizygous twins has been established, and is known to be greater in CD. The existence of familial aggregation has been established, together with the concomitant presence of other well known autoimmune disorders or genetic syndromes (1-4).

The search for genes conditioning susceptibility to IBD is difficult, due to the complexity of the genetic factors, including the absence of a simple Mendelian transmission pattern, incomplete penetrance of the genes, and the genetic heterogeneity involved. IBD is a polygenic disorder in which a number of genes are implicated in susceptibility to develop the disease (5).

Most investigators agree that the most consistent gene in predicting susceptibility to CD but not to UC is located in chromosome 16, and has been called NOD2 (nucleotide oligomerization domain), now referred to as CARD15 (C-terminal caspase recruitment domains) (6$8)$. This gene encodes for a protein expressed by monocytes, macrophages, dendritic cells and epithelial cells. Three polymorphisms of this gene (R702W, G908R and L1007fs) have been associated with altered activation of nuclear factor NF-kB (8). The presence of these three mutations represents over $82 \%$ of all possible mutations of the gene, while the remaining 27 are unlikely to generate functional changes in the protein they encode for (9).

The present study reviews the role of these mutations in $\mathrm{CD}$, the way in which they influence the clinical characteristics of $\mathrm{CD}$, the different prevalences found worldwide and even within Spain, and finally their present and future usefulness in the management of IBD.

\section{ROLE OF THE MUTATIONS OF THE NOD2/CARD15 GENE IN CD}

The importance of the mutations of the NOD2/CARD15 gene in CD is not only base on the consistency of the interstudy reproducibility of the association between these mutations and the susceptibility to develop CD.

The most important aspect of the discovery of mutations of the NOD2/CARD15 gene is that it has allowed the development of interesting theories designed to explain the cause of CD based on the existence of an alteration in the regulation of the host immune response towards the bacteria found within the bowel lumen. The association of NOD2/CARD15 mutations with CD, with Blau syndrome (a dominant autosomal disorder characterized by arteritis, uveitis, skin rash and the presence of granulomas), and possibly with sarcoidosis in the early stages of life, suggests that this gene influences the development of granulomas in granulomatous diseases. Granuloma formation usually takes place as a response on the part of the healthy host to intracellular microorganisms (mycobacteria and fungi), and is dependent upon the activation of Th1 lymphocytes and their secreted cytokines -mainly interleukin-12, interferon-gamma and tumor necrosis factor (TNF)- (10).

NOD2/CARD15 gene deficiency alters the NOD2/CARD15 receptor; this in turn induces alterations in Peyer's patch function within the small bowel, characterized by an exaggerated immune response and increased intestinal permeability -thereby contributing to chronic intestinal inflammation (11). Therefore, patients who carry the mutations of the NOD2/CARD15 gene would be unable to adequately control bacterial infections, fundamentally as a consequence of defective recognition of muramyl dipeptide protein (MDP) found in the wall of the cell envelope of enteroinvasive bacteria such as enteroinvasive Escherichia coli (12) and mycobacteria (13). However, it should be noted that eight years after confirmation that these mutations are associated to susceptibility to developing $\mathrm{CD}$, we still do not know the precise consequences of these mutations in relation to the functions of the proteins they encode for.

\section{GEOGRAPHIC AND ETHNIC DIFFERENCES IN THE PREVALENCE OF CARD15/NOD2 GENE MUTATIONS THROUGHOUT THE WORLD}

Important geographic and population variations have been described both in relation to the risk of developing $\mathrm{CD}$ and as regards the presence of the NOD2/CARD15 gene variants in patients with $\mathrm{CD}$. The prevalence of $\mathrm{CD}$ patients who carry at least one susceptibility allele of the CARD15 gene varies from $27-50 \%$ in most Caucasian European populations. The multicenter study published by Lesage et al. (9), with the participation of several European countries, reported a carrier frequency of $50 \%$. Other studies carried out in central European countries have recorded similar results. Thus, in Great Britain $(\mathrm{Ox}-$ ford) the carrier frequency was found to be $38.5 \%$ (12), versus $46.3 \%$ in Belgium (14), 38.2\% in Italy (15), 38\% in France (16), 36.5\% in Germany (17), and $46 \%$ in the Czech Republic (18). However, in the Scandinavian countries, which are generally characterized by more homogeneous populations, the observed frequencies were much lower than expected for European populations: $15.5 \%$ in Finland (19), 15.2\% in Sweden (20), and 21\% in Denmark (21).

In Caucasian populations relatively far from Europe but directly descending from the European population with hardly no racial mixing, the reported frequencies have been similar to those found in central Europe. In the United States, the percentage carrier rate ranges from 
$36.5-45 \%(22,23)$, versus 32.5 to $45 \%$ in Canada (the latter percentage in Quebec) $(24,25)$, and $36.7 \%$ in Australia (26). On the other hand, it is very notorious that not a single variant has been identified in the Asian populations of Japan (27), Korea (28), China $(29,30)$ and India (31), in either patients or controls -with the added feature that these populations are comparatively much more homogeneous. More recently a study has been published in Iran (32), though involving only few patients, with a reported 32\% mutation rate in patients with $\mathrm{CD}$. This serves to confirm that these mutations may also be present in Asian populations. In other countries of Arab origin such as Turkey (33), the frequency of CD patients who carry these mutations was seen to be very low (10.7\%), while in Tunisia (34) the frequency was so low that there were no statistically significant differences with respect to the control group. In the other study carried out in an African population, specifically among $\mathrm{Ne}$ groes in South Africa, practically no mutations were identified (35).

As a curiosity, only two studies have been carried out in Latin America. One of them, conducted in Chile (36), involves such a small patient series that few conclusions can be drawn, though the results suggest a very low number of carriers. The other study was carried out in Brazil (37), with a mutation frequency in CD patients of $30 \%$. It is important to bear in mind that the Brazilian population is very heterogeneous, with a large number of individuals of German descent.

Based on these data, it seems clear that the ethnic background of the patients plays a fundamental role in defining the number of mutation carriers. In a study conducted in Israel (38) among Jews of both Ashkenazi and non-Ashkenazi origin, mutations were recorded in $27 \%$ of the cases, with no differences between the two origins. However, in another recent study carried out in the same country in a population of Arab origin (39), the observed frequency of mutation carriers was very low (less than $9 \%$ ), with no differences versus the controls. Ethnic differences have also been documented in other countries such as New Zealand, where patients of Maori origin were seen to have fewer mutations (40). In the United Kingdom, important differences have been observed between the population of Oxford (12) and the Scottish population (41).

\section{GEOGRAPHIC DIFFERENCES IN SPAIN}

In Spain there are not so many ethnic differences, though important differences in the prevalence of CARD15 mutations have been observed among the inhabitants of different Spanish Autonomous Communities. As regards the percentage of $\mathrm{CD}$ patients presenting some of the mentioned mutations, the first published study, carried out in Madrid San Carlos Clinic Hospital (42), reported a frequency of $32.8 \%$ among patients, and $10.7 \%$ in the controls. The next study, carried out a few months after the first, in Galicia, reported mutations in $27.9 \%$ of the patients and in $15.2 \%$ of the controls (43). Posteriorly, two independent studies have been made in Catalonia: one without a control series (44), in which the mutation rate in the patients was seen to be $30.5 \%$, and another study involving a control group (45), in which the carrier rate was 30.9 and $6 \%$ among patients and controls, respectively. Another study has been carried out in Toledo (46), in which the carrier rate was $27.3 \%$ and $13.3 \%$ among patients and controls, respectively. The last Spanish study published to date has been carried out in Asturias (47), and has been the only study in this country that has failed to record statistically significant differences in carrier rate between CD patients (17.3\%) and controls (17.6\%). Table I details the presence of each of the three mutations in patients and controls, in the published Spanish studies.

As a curiosity, and given the proximity to some Spanish populations, another two studies have been carried out on the Iberian Peninsula, including one in Oporto (Portugal) (48) with a carrier rate of 34.6 and $12.9 \%$ among patients and controls, respectively. However, in

Table I. Frequency of carriers of the principal mutations of the CARD15 gene in the different Spanish studies

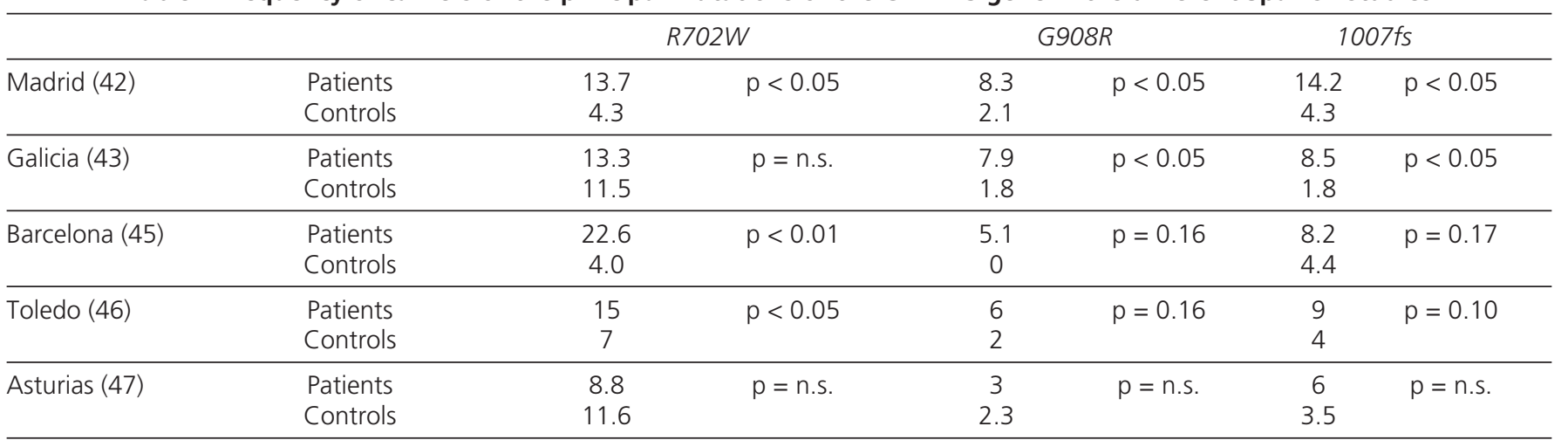


the other study, carried out in Lisbon (49), the documented carrier rate was $21 \%$ among the patients and $16 \%$ in the controls -no statistically significant differences being observed between the two groups. Nevertheless, it must be mentioned that this study involved a very limited number of subjects.

\section{IMPACT OF THE MUTATIONS UPON CROHN'S DISEASE}

It is important to know the usefulness of the genetic mutations once the diagnosis of the disease has been established. Consistent results have been published as regards the relationship between the mutations of the CARD15 gene and the location of the disease. In a British study (12), the mutations were only significantly correlated to ileal disease, with a hazard ratio of 4 in the presence of one mutation, and 30 in the presence of two or more mutations. These observations have been corroborated by other studies, as well as by a metaanalysis published by Economou -OR 2.53 (95\% CI: $2.013 .16)-(50)$. In addition to a greater association to ileal forms of the disease, other studies have found the CARD15/NOD2 variants to be inversely correlated to $\mathrm{CD}$ of the colon $(9,25)$. A probable explanation for these results is the great difference between the immune tolerance mechanisms of the ileum and colon -the latter being exposed to a greater bacterial concentration than the ileum. In this context, the colon may use immunological mechanisms that are not dependent upon CARD15 function (51).

Although the results are less consistent, the mentioned metaanalysis (50) has documented an association between the CARD15 variants and patients with fibro-stricturing forms of CD -OR 1.94 (95\%CI: 1.61-2.34)-. On separately analyzing the main studies, in most of them it is seen that patients with stricturing $C D$ have a larger number of mutations than the rest of the patients $(9,12,22)$-the association with this form of the disease being stronger among patients presenting the insertion variant (L1007insC) (52). The correlation of the mutations to the stricturing forms of $\mathrm{CD}$ requires more detailed study in the future, firstly because the evolutive profile of $\mathrm{CD}$ is known to be able to change over the years, and secondly because stricturing disease is positively correlated to ileal disease -and this could represent a source of bias upon interpreting the results.

Regarding the association with the more severe forms of the disease, most of the published studies $(7,15,19,48,53)$ point to an increased need for ileal surgery in patients with CARD15 mutations -though other authors have not been able to confirm this association $(38,54)$. In most studies, the mutation with the strongest correlation has been insertion (1007fs). In fact, in a study in which only this mutation was analyzed, an association to surgery was also found (55).
Some studies deserve special mention, since they contribute different concepts. Thus, Kugathasan et al. (23), in a pediatric population, found that patients with CARD15 mutations had an increased risk of surgery (hazard ratio 5.8; $\mathrm{p}<0.0001$ ), and surgery was moreover indicated at an earlier stage (hazard ratio 2.24). In three independent studies, one carried out in Germany (17), another in Italy (56) and another in Spain by the group belonging to Barcelona Clinic Hospital (44), patients with mutations of the gene presented an increased risk of repeated surgery, and such surgery was moreover required earlier.

Considering the need for surgery as an indicator of severity, these results would agree with the idea that the CARD15 gene plays an important role in establishing susceptibility to more severe presentations of $\mathrm{CD}$. However, despite the relationship between these mutations and the need for surgery in CD, it must be mentioned that the proportion of patients who carry mutations in the population needing surgery is still too small to allow its use as a predictive tool. In addition, it must be taken into account that there are always a number of patients who require surgery but do not carry mutations of this gene.

\section{CAN THE NOD2/CARD15 MUTATIONS BE APPLIED IN ROUTINE CLINICAL PRACTICE?}

At present, genetic testing in IBD is not prepared for clinical application. The main reason is that to date most of the genes only marginally increase the risk of developing the disease, and moreover many healthy individuals who will not develop the disease carry these mutations. Indeed, many individuals with NOD2/CARD15 mutations will not develop CD. The hazard ratio in the presence of a single mutation is $2-3$, though this figure increases 20-40 in the presence of two mutations $(9,12,14-18)$. With the current prevalence of $\mathrm{CD}$ in $\mathrm{Eu}-$ rope, it can be stated that the hazard ratio for developing $\mathrm{CD}$ in the presence of two mutations in the European population is $4-8 \%(9,12,14-18)$, though penetrance is very low: less than $10 \%$ of all carriers of two mutations will develop the illness. This means that other genes and environmental stimuli are required to develop CD (57). A very interesting aspect is that the determination of CARD15/NOD2 mutations can identify individuals at high risk of developing $\mathrm{CD}$, such as first-degree relatives of patients with $\mathrm{CD}$. A metaanalysis (50) has estimated that the presence of any of the NOD2/CARD15 mutations increases the risk of familial CD -OR 1.41 (95\%CI: 1.17-1.69)-. However, the current lack of strategies for preventing such individuals from developing CD speaks against the determination of these mutations among the relatives of CD patients. Theoretically, in this group of high risk individuals it could be possible for example to genetically modify these mutations through gene therapy; 
reduce the specific bacterial antigen burden in the bowel lumen (in view of the above mentioned probability that the susceptibility genes are specific of certain bacteria - i.e., the NOD2/CARD15 mutations and MDP protein of the bacterial cell wall); and avoid certain environmental factors associated with the onset of bowel inflammation and rupture of the mucosal barrier (58). Among such factors, mention can be made of smoking, which is an exogenous influence related to susceptibility and a poorer course of CD. No greater or lesser association has been recorded among the NOD2/CARD15 mutations, smoking, and CD $(9,53)$.

Recently it has been reported that a combination of four genetic markers and smoking only increases the post-test probability of developing CD by $1 \%$-thus suggesting that $99 \%$ of all individuals with a positive test result will never suffer CD (59).

There is a need to develop biomarkers capable of predicting a more aggressive course of IBD in both CD and in UC, with a view to introducing more aggressive therapies in an earlier stage, and even for developing strategies allowing us to use biological therapies as first treatment choice (i.e., "top-down" strategies). However, since genetic factors in turn are influenced by environmental factors, strategies are clearly needed that combine genetic factors with other factors such as serological markers and clinical parameters, in order to predict a more aggressive clinical course of the disease, and to classify patients as being at high or low risk, in order to define the best treatment option for each subject. Although a number of studies have related NOD2/CARD15 mutations to an increased need for surgery $(7,15,19,48,53)$, and thus to more severe forms of the disease, it is presently not possible to use them as a single marker of disease severity. The association of such mutations to ileal CD (50) and stricturing behavior $(9,12,22,50)$ make them interesting for establishing a molecular classification of CD, albeit only with application to the investigational setting.

Pharmacogenetics aims to explain how genes interfere with drug metabolic pathways and can influence treatment response and toxicity. NOD2/CARD15 mutations have also been postulated as being responsible for the differences in treatment response among patients administered therapies such as anti-TNF agents, due to their capacity to produce changes in NF-kB activation and thus in the production of anti-TNF effects. However, it has not been possible to demonstrate this association in three independent cohorts of patients treated with infliximab $(60,61)$.

\section{WHAT MUST WE TELL OUR PATIENTS?}

Our patients must be informed that genetic techniques do not yet have an impact upon the diagnosis and predic- tion of the clinical course of IBD, though interesting work is being done in this field. At present, it is not worthwhile to conduct the genetic sequencing of patients for individualized clinical purposes. Rather, patients should be encouraged to participate in well designed studies to allow us to complete the genetic map of IBD, reproduce the information we have collected to date, and identify therapeutic targets for controlling IBD.

\section{REFERENCES}

1. Yang H, Rotter J. The genetic background of inflammatory bowel disease. Hepatogastroenterology 2000; 47: 5-14.

2. Duerr R. The genetics of inflammatory bowel disease. Gastroenterol Clin N Am 2002; 31: 63-76.

3. Ahmad T, Tamboli C, Jewell D, et al. Clinical relevance of advances in genetics and pharmacogenetics of IBD. Gastroenterology 2004; 126 1533-49.

4. Ahmad T, Satsangi J, McGovern D, et al. Review article: the genetics of inflammatory bowel disease. Aliment Pharmacol Ther 2001; 14: 731-48.

5. Mendoza JL, Taxonera C. Clinical value of gene NOD2/CARD15 mutations in Crohn's disease. Rev Esp Enferm Dig 2005; 97(8): 541-69.

6. Hugot JP, Chamaillard M, Zouali H, et al. Associaton of NOD2 leucine-rich repeat variants with susceptibility to Crohn's disease. Nature 2001; 411: 599-603.

7. Hampe J, Cuthbert A, Croucher P, et al. Association between insertion mutation in NOD2 gene and Crohn disease in German and British populations. Lancet 2001; 357: 1925-7.

8. Ogura Y, Bonen DK, Inohara N, et al. A frameshit mutation in NOD2 associated with susceptibility to Crohn's disease. Nature 2001; 411: 603-6.

9. Lesage S, Zouali H, Cezard JP, et al. CARD15/NOD2 mutational analysis and genotype-phenotype correlation in 612 patients with inflammatory bowel disease. Am J Hum Genet 2002; 70: 845-57.

10. Henckaerts L, Vermeire S. NOD2/CARD15 disease associations other than Crohn's disease. Inflamm Bowel Dis 2007; 13(2): 235-41.

11. Barreau F, Meinzer U, Chareyre F, et al. CARD15/NOD2 is required for Peyer's patches homeostasis in mice. PLoS One 2007; 2(6): e523.

12. Ahmad T, Armuzzi A, Bunce M, et al. The molecular classification of the clinical manifestations of Crohn's disease. Gastroenterology 2002; 122: 854-66.

13. Ferwerda G, Kullberg BJ, de Jong DJ, et al. Mycobacterium paratuberculosis is recognized by toll-like receptors and NOD2. J Leukoc Biol 2007; 82(4): 1011-8.

14. Esters N, Pierik M, van Steen K, et al. Transmission of CARD15 (NOD2) variants within families of patients with inflammatory bowel disease. Am J Gastroenterol 2004; 99: 299-305.

15. Annese V, Lombardi G, Perri F, et al. Variants of CARD15 are associated with an aggressive clinical course of Crohn's disease --an IG-IBD study. Am J Gastroenterol 2005; 100: 84-92.

16. Heresbach D,Gicquel-Douabin V, Birebent B, et al. NOD2/CARD15 gene polymorphisms in Crohn's disease: a genotype- phenotype analysis. Eur J Gastroenterol Hepatol 2004; 16: 55-62.

17. Büning $\mathrm{C}$, Genschel $\mathrm{J}$, Bühner $\mathrm{S}$, et al. Mutations in the NOD2/CARD15 gene in Crohn's disease are associated with ileocecal resection and are a risk factor for reoperation. Aliment Pharmacol Ther 2004; 19: 1073-8.

18. Hradsky O, Lenicek M, Dusatkova P, et al. Variants of CARD15, TNFA and PTPN22 and susceptibility to Crohn's disease in the Czech population: high frequency of the CARD15 1007fs. Tissue Antigens 2008; 71: 538-47.

19. Heliö T, Halme L, Lappalainen M, et al. CARD15/NOD2 gene variants are associated with familially occurring and complicated forms of Crohn's disease. Gut 2003; 52: 558-62.

20. Törkvist L, Noble CL, Lördal M, et al. Contribution of CARD15 variants in determining susceptibility to Crohn's disease in Sweden. Scand J Gastroenterol 2006; 41: 700-5. 
21. Ernst A, Jacobsen B, Østergaard M, et al. Mutations in CARD15 and smoking confer susceptibility to Crohn's disease in the Danish population. Scand J Gastroenterol 2007; 42: 1445-51.

22. Abreu MT, Taylor KD, Lin YC, et al. Mutations in NOD2 are associated with fibrostenosing disease in patients with Crohn's disease. Gastroenterology 2002; 123: 679-88.

23. Kugathasan S, Collins N, Maresso K, et al. CARD15 gene mutations and risk for early surgery in pediatric-onset Crohn's disease. Clin Gastroenterol Hepatol 2004; 2: 1003-9.

24. Newman B, Silverberg MS, Gu X, et al. CARD15 and HLA DRB1 alleles influence susceptibility and disease localization in Crohn's disease. Am J Gastroenterol 2004; 99: 306-15.

25. Vermeire S, Wild G, Kocher K, et al. CARD15 genetic variation in a Quebec population: prevalence, genotype-phenotype relationship, and haplotype structure. Am J Hum Genet 2002; 71: 74-83.

26. Cavanaugh JA, Adams KE, Quak EJ, et al. CARD15/NOD2 risk alleles in the development of Crohn's disease in the Australian population. Ann Hum Genet 2003; 67: 35-41.

27. Inoue N, Tamura K, Kinouchi Y, et al. Lack of common NOD2 variants in Japanese patients with Crohn's disease. Gastroenterology 2002; 123: 86-91.

28. Croucher PJ, Mascheretti S, Hampe J, et al. Haplotype structure and association to Crohn's disease of CARD15 mutations in two ethnically divergent populations. Eur J Hum Genet 2003; 11: 6-16.

29. Leong RW, Armuzzi A, Ahmad T, et al. NOD2/CARD15 gene polymorphisms and Crohn's disease in the Chinese population. Aliment Pharmacol Ther 2003; 17: 1465-70.

30. Li M, Gao X, Guo CC, Wu KC, et al. OCTN and CARD15 gene polymorphism in Chinese patients with inflammatory bowel disease. World J Gastroenterol 2008; 14: 4923-7.

31. Pugazhendhi S, Amte A, Balamurugan R, et al. Common NOD2 mutations are absent in patients with Crohn's disease in India. Indian J Gastroenterol 2008; 27: 201-3.

32. Derakhshan F, Naderi N, Farnood A, et al. Frequency of three common mutations of CARD15/NOD2 gene in Iranian IBD patients. Indian J Gastroenterol 2008; 27: 8-11.

33. Uyar FA, Over-Hamzaoğlu H, Türe F, et al. Distribution of common CARD15 variants in patients with sporadic Crohn's disease: cases from Turkey. Dig Dis Sci 2006; 51: 706-10.

34. Zouiten-Mekki L, Zaouali H, Boubaker J, et al. CARD15/NOD2 in a Tunisian population with Crohn's disease. Dig Dis Sci 2005; 50 : $130-5$

35. Zaahl MG, Winter T, Warnich L, et al. Analysis of the three common mutations in the CARD15 gene (R702W, G908R and 1007fs) in South African colored patients with inflammatory bowel disease. Mol Cell Probes 2005; 19: 278-81.

36. Figueroa C, Peralta A, Herrera L, et al. NOD2/CARD15 and Toll-like 4 receptor gene polymorphism in Chilean patients with inflammatory bowel disease. Eur Cytokine Netw 2006; 17: 125-30.

37. Baptista ML, Amarante H, Picheth G, et al. CARD15 and IL23R influences Crohn's disease susceptibility but not disease phenotype in a Brazilian population. Inflamm Bowel Dis 2008; 14: 674-9.

38. Fidder HH, Olschwang S, Avidan B, et al. Association between mutations in the CARD15 (NOD2) gene and Crohn's disease in Israeli Jewish patients. Am J Med Genet A 2003; 121: 240-4.

39. Karban A, Atia O, Leitersdorf E, et al. The relation between NOD2/CARD15 mutations and the prevalence and phenotypic heterogeneity of Crohn's disease: lessons from the Israeli Arab Crohn's disease cohort. Dig Dis Sci 2005; 50: 1692-7.

40. Gearry RB, Lea RA, Roberts RL, et al. CARD15 allele frequency differences in New Zealand Maori: ancestry specific susceptibility to Crohn's disease in New Zealand? Gut 2006; 55: 580.

41. Arnott ID, Nimmo ER, Drummond HE, et al. NOD2/CARD15, TLR4 and CD14 mutations in Scottish and Irish Crohn's disease patients: evidence for genetic heterogeneity within Europe? Genes Immun 2004; 5: $417-25$.
42. Mendoza JL, Murillo LS, Fernández L, et al. Prevalence of mutations of the NOD2/CARD15 gene and relation to phenotype in Spanish patients with Crohn disease. Scand J Gastroenterol 2003; 38: 1235-40.

43. Núñez C, Barreiro M, Domínguez Muñoz E. CARD15 Mutations in patients with Crohn's disease in a homogeneous Spanish population. Am J Gastroenterol 2004; 99: 450-6.

44. Alvarez-Lobos M, Arostegui JI, Sans M, et al. Crohn's disease patients carrying Nod2/CARD15 gene variants have an increased and early need for first surgery due to stricturing disease and higher rate of surgical recurrence. Ann Surg 2005; 242: 693-700.

45. Cantó E, Ricart E, Busquets D, et al. Influence of a nucleotide oligomerization domain 1 (NOD1) polymorphism and NOD2 mutant alleles on Crohn's disease phenotype. World J Gastroenterol 2007; 13 : 5446-53.

46. De Diego C, Alcántara M, Valle J, et al. Frequency of CARD15 polymorphisms in patients with Crohn's disease from Toledo, Spain: genotype-phenotype correlation. Genet Test 2006; 10: 178-85.

47. Rodrigo L, Martínez-Borra J, Garrote JA, et al. CARD15 mutations are poorly related to Crohn's disease phenotypes in Asturias. Rev Esp Enferm Dig 2007; 99: 570-757.

48. Ferreira AC, Almeida S, Tavares M, et al. NOD2/CARD15 and TNFA, but not IL1B and IL1RN, are associated with Crohn's disease. Inflamm Bowel Dis 2005; 11: 331-9.

49. Vind I, Vieira A, Hougs L, et al. NOD2/CARD15 gene polymorphisms in Crohn's disease: a genotype-phenotype analysis in Danish and Portuguese patients and controls. Digestion 2005; 72: 156-63.

50. Economou M, Trikalinos TA, Loizou KT, et al. Differential effects of NOD2 variants on Crohn's disease risk and phenotype in diverse populations: a metaanalysis. Am J Gastroenterol 2004; 99: 393-404.

51. Colombel JF. The CARD15 (also known as NOD2) gene in Crohn's disease: Are there implications for current clinical practice? Clin Gastrenterol Hepatol 2003; 1: 5-9.

52. Radlmayr M, Torok HP, Martin K, et al. The c-insertion mutation of the NOD2 gene is associated with fistulizing and fibroestenotic phenotypes in Crohn's disease (letter). Gastroenterology 2002; 122: 2091-2

53. Barreiro M, Núñez C, Domínguez-Muñoz JE, et al. Association of NOD2/CARD15 mutations with previous surgical procedures in Crohn's disease. Rev Esp Enferm Dig 2005; 97: 547-53.

54. Renda MC, Orlando A, Civitavecchia G, et al. The role of CARD15 mutations and smoking in the course of Crohn's disease in a Mediterranean area. Am J Gastroenterol 2008; 103: 649-55.

55. Seiderer J, Schnitzler F, Brand S, et al. Homozygosity for the CARD 15 frameshift mutation 1007fs is predictive of early onset of Crohn's disease with ileal stenosis, entero-enteral fistulas, and frequent need for surgical intervention with high risk of re-stenosis. Scand J Gastroenterol 2006; 41: 1421-32.

56. Maconi G, Colombo E, Sampietro GM, Lamboglia F, D'Incà R, Daperno M, et al. CARD15 gene variants and risk of reoperation in Crohn's disease patients. Am J Gastroenterol 2009; 104(10): 2483-91.

57. Henckaerts L, Vermeire S. Genética de la enfermedad inflamatoria intestinal. En: Gassull MA, Gomollon F, Hinojosa J, Obrador A, editores. Enfermedad inflamatoria intestinal. Madrid: Aran Ediciones SL; 2007. p. 59-73.

58. Sartor RB. Clinical applications of advances in the genetics of IBD. Rev Gastroenterol Disord 2003; 3(Supl. 1): S9-17.

59. McGovern DP, Butler H, Ahmad T, et al. TUCAN (CARD8) genetic variants and inflammatory bowel disease. Gastroenterology 2006; 131(4): 1190-6.

60. Vermeire S, Louis E, Rutgeerts $\mathrm{P}$, et al. NOD2/CARD15 does not influence response to infliximab in Crohn's disease. Gastroenterology 2002; 123(1): 106-11.

61. Mascheretti S, Hampe J, Croucher PJ, et al. Response to infliximab treatment in Crohn's disease is not associated with mutations in the CARD15 (NOD2) gene: an analysis in 534 patients from two multicenter, prospective GCP-level trials. Pharmacogenetics 2002; 12(7): 509-15. 